\title{
Rapid phlorotannin induction and relaxation in five Washington kelps
}

\author{
Kamille Hammerstrom ${ }^{1, *}$, Megan N. Dethier ${ }^{2}$, David O. Duggins ${ }^{2}$ \\ ${ }^{1}$ University of South Carolina, Marine Science Program, Columbia, South Carolina 29208, USA \\ ${ }^{2}$ Friday Harbor Laboratories, University of Washington, Friday Harbor, Washington 98250, USA
}

\begin{abstract}
Wounding of both terrestrial and marine plants is known to induce chemical responses in the plants; the induced compounds may defend against herbivory or act in wound-healing processes. We demonstrate here, for the first time, induction of phlorotannins in kelps (Phaeophyta, Laminariales). an important and widespread group of marine benthic algae. The rapid response of kelps to mechanical wounding contrasts with previously published work on other marine algae, where response has been slower. In 4 of the 5 species tested, induction (increases of approximately 30 to $90 \%$ of original levels) occurred very rapidly, within 1 to $3 \mathrm{~d}$ of wounding, although the magnitude and duration of the induction varied among species and tissue types. Many induced responses persisted for 5 to $7 \mathrm{~d}$ and then relaxed. Relaxation times are a critical component in the hypothesized cost-effectiveness of induced versus constitutive defenses, and this is one of the first attempts to measure relaxation times of chemical defenses in marine algae. The temporal persistence of the response suggests an antiherbivory rather than a wound-healing function for induction of phlorotannins, although this needs further testing.
\end{abstract}

KEY WORDS: Kelp phlorotannins - Induction - Relaxation - Chemical defense - Wound healing Herbivory

\section{INTRODUCTION}

Brown algae, kelps in particular (Phaeophyta, Laminariales), are a critically important component of intertidal and subtidal benthic marine communities in temperate seas (Dayton 1985, Schiel \& Foster 1986) and form some of the most productive plant communities in the world (Mann 1973, 1982). Kelps contribute to secondary production throughout the nearshore food web (Duggins et al. 1989) and are fed upon by a variety of invertebrate and vertebrate herbivores, yet may persist for years or decades as individuals and in patches (Dayton et al. 1984).

Many brown algae, including some kelps, contain substantial concentrations of polyphenolic compounds known as phlorotannins, acetate-malonate derived polymers of phloroglucinol (1,3,5-trihydroxybenzene)

\footnotetext{
- Current address: South Carolina Department of Natural Resources, Marine Resources Research Institute, Charleston, South Carolina 29412, USA.

E-mail: hammerstromk@mrd.dnr.state.sc.us
}

(Ragan \& Glombitza 1986). Terrestrial plant tannins (analogous to marine phlorotannins) may increase plant fitness by contributing to increased resistance to herbivory, ultraviolet radiation, or disease (Karban \& Myers 1989, Herms \& Mattson 1992, Waterman \& Mole 1994, Wold \& Marquis 1997). Likewise, algal phlorotannins have been found to deter herbivory by gastropods, urchins, and amphipods (Geiselman \& McConnell 1981, Anderson \& Velimirov 1982, Steinberg 1984, 1985, 1988, Johnson \& Mann 1986, Denton \& Chapman 1991, Winter \& Estes 1992, Yates \& Peckol 1993, Poore 1994, Steinberg et al. 1995, but for exceptions see Steinberg \& van Altena 1992, Steinberg 1995, Targett et al. 1995). Phlorotannins may also act in wound-healing processes (Faberberg \& Dawes 1976, Azanza-Corrales \& Dawes 1989), prevent microbial attack (Sieburth \& Conover 1965), act as antifouling agents (Sieburth \& Conover 1965, Langlois 1975, Alogily \& Knight-Jones 1977, but see Jennings \& Steinberg 1997), and protect algae from ultraviolet radiation (Pavia et al. 1997). Anti-algal, anti-larval, and antifungal activities have also been attributed to phloro- 
tannins (see review by Ragan \& Glombitza 1986). Production of tannins and phlorotannins almost certainly results in a cost to the organism, such as increased metabolic or nutrient demands and decreased growth rates (Hay \& Fenical 1988, Karban \& Myers 1989, Herms \& Mattson 1992, Steinberg 1995, Zangerl et al. 1997), although costs have proven difficult to detect and quantify (Simms \& Rausher 1987, Pfister 1992, Pavia \& Åberg 1996, Zangerl et al. 1997, T. Arnold pers. comm.).

Phlorotannin levels vary on many spatial and temporal scales. Within species, phlorotannins may be differentially allocated to reproductive or meristematic tissue (Steinberg 1984, Ragan \& Glombitza 1986, Tugwell \& Branch 1989, Pfister 1992). Levels may vary seasonally (Ragan \& Glombitza 1986) and be influenced by nutrient availability (Yates \& Peckol 1993, Arnold et al. 1995, Peckol et al. 1996), light levels (Ragan \& Jensen 1979, Pavia et al. 1997), tidal height (Marlinez 1996), and life history stage (Denton et al. 1990). Phlorotannins also vary geographically (Targett et al. 1995, Pavia \& Åberg 1996, K. L. Van Alstyne, J. J. McCarthy, C. L. Hustead \& D. O. Duggins unpubl. data), although there is debate over geographic patterns.

Phlorotannins are known to occur as constitutive and inducible defenses. As a constitutive defense, phlorotannins should be present all the time at a level that inhibits or counteracts critical forms of disturbance (i.e. herbivory, infection, UV radiation). For example, a constitutive phlorotannin defense against herbivory would be most beneficial in habitats where herbivore pressure is predictable (Herms \& Mattson 1992), and against herbivores that are highly mobile, such as a fish or urchin that moves on to a more palatable food after a few bites of a distasteful one (Herms \& Mattson 1992, Paul \& Van Alstyne 1992, Hay 1996). Alternatively, phlorotannins may occur as an inducible defense, always present in low levels, but produced in higher levels as a response to a disturbance (Schultz 1988, Harvell 1990). An inducible phlorotannin defense against herbivory would be most beneficial in habitats where herbivory is unpredictable (Harvell 1990. Herms \& Mattson 1992) and should affect less mobile animals such as microbes or small grazers; these organisms encounter spatially limited areas of a plant numerous times within a short period, and therefore may not have the ability to easily escape the induced response (Herms \& Mattson 1992, Hay 1996).

Phlorotannins are inducible in some fucoid brown algae (Van Alstyne 1988, Yates \& Peckol 1993, Peckol et al. 1996. Pavia et al. 1997, but for exceptions see Lowell et al. 1.991, Steinberg 1994). Four studies have sought evidence for induction in kelp blade tissue and found none (Pfister 1992, Steinberg 1994, 1995, Martinez 1996). Martinez (1996) measured phlorotannin levels $2 \mathrm{~d}$ after damage in a single plant. In the other 3 studies, plant responses were sought from $4 \mathrm{~d}$ (Steinberg 1994) to $4 \mathrm{wk}$ (Steinberg 1995) to $4 \mathrm{mo}$ (Pfister 1992) after damage (actual or simulated herbivory). Studies of the brown alga Padina gymnospora (Renaud et al. 1990) and the green alga Halimeda sp. (Paul \& Van Alstyne 1992) demonstrate that some algae are capable of responding to both simulated and actual herbivory in as little as $1 \mathrm{~d}$ following damage; this induced response may persist for as few as $5 \mathrm{~d}$ (Renaud et al. 1990) or as many as $14 \mathrm{~d}$ (Peckol et al. 1996). The time course of induction can be crucial to its success as a defense; clearly, even $4 \mathrm{~d}$ may be too long for a kelp to respond to disturbance. In addition, the blade is not the only tissue vulnerable to attack, yet no studies have tested for induction in stipes or holdfasts.

The roles of induced versus constitutive defenses are important to the ecology and evolution of algal-herbivore interactions (Simms \& Rausher 1987, Harvell 1990, Paul 1992, Steinberg 1994). To understand the general applicability of induced defense models (Steinberg 1994), we must discover the prevalence (or indeed presence) of inducible responses, both within tissues of a species and among related species (e.g. Laminariales). To serve effectively as an induced defense following a single disturbance event, phlorotannin levels in kelps should increase and relax on much shorter time scales than previously measured. In order to test this hypothesis, we systematically wounded 5 species of kelps found in the San Juan Islands, Washington (USA), and measured changes in phlorotannin concentration near the wound site. In accordance with optimal defense theory, we predicted that phlorotannin levels would increase very rapidly following wounding but return to pre-wound levels if no further damage was done to the plant (Rhoades 1979).

\section{METHODS}

Study sites and organisms. All laboratory work was conducted in 1995 at the University of Washington's Friday Harbor Laboratories in the San Juan Islands, Washington. The region harbors a range of intertidal and subtidal kelp habitats, from high current, moderately exposed areas to very protected areas with little or no current. Much of the rocky subtidal zone (at depths of $<20 \mathrm{~m}$ ) in the Friday Harbor area is dominated by Agarum fimbriatum Harvey. Pleurophycus gardneri Setchell \& Saunders is patchily distributed in the San Juan Islands, from the low intertidal to upper subtidal zones, and primarily in areas of high current. The blade of $P$. gardneri is deciduous, shed entirely each fall and regenerated a few weeks later (Germann 
1986). Laminaria complanata is found only in Washington and British Columbia (Canada). Both L. complanata and L. groenlandica Rosenvinge occupy the shallow subtidal zone in sheltered areas. A. fimbriatum, P. gardneri, L. groenlandica, and L. Complanata are all perennial, understory (sub-surface canopy) kelps. Hedophyllum sessile (C. Agardh) Setchell is the only truly intertidal kelp in the area, occurring in the low intertidal zone in moderately wave-exposed areas. $H$. sessile is also perennial, probably living for 2 to 3 yr.

Local kelp beds harbor many invertebrate herbivores. In subtidal areas urchins (Strongylocentrotus droebachiensis and $S$. franciscanus) are critical grazers, but are patchily distributed. Gastropod grazers (on kelps or epiphytes), primarily the mesogastropods Lacuna vincta, Calliostoma spp., and Margarites spp., are common. Herbivorous fishes are rare in the subtidal areas. Other subtidal grazers include the amphipod Ampithoe lacertosa, isopods Idotea spp. and Limnoria spp., and polychaetes. At the intertidal site, common herbivores include the chiton Katharina tunicata, the limpet Tectura scutum, and majid crabs.

Induction experiments. After one experiment in which a subtidal species was tagged and wounded in situ (Laminaria complanata), we decided that it was more feasible to collect subtidal plants (Agarum fimbriatum, Pleurophycus gardneri, L. groenlandica) from various field sites near San Juan Island and manipulate them on accessible racks suspended from a floating dock near the lab. The spring Hedophyllum sessile experiment was conducted in situ because low daytime tides made field work possible, but, in the fall, $H$. sessile plants were also relocated to a rack. During collection, plant holdfasts were carefully removed from the substrate with a scalpel, and plants sustaining visible damage were discarded. Once cleaned of herbivores, plant holdfasts were attached to PVC racks with tygon tubing ( $L$. groenlandica adults, $H$. sessile) or nylon rope (A. fimbriatum, $P$. gardneri, L. groenlandica juveniles). Plants were allowed to acclimate for several weeks on the racks, and checked periodically throughout the experiment; no further herbivores were found on them. Relocated A. fimbriatum and P. gardneri were suspended at a depth of approximately $7.5 \mathrm{~m}$, similar to the depths at which they were collected. L. groenlandica plants were collected at a variety of depths and suspended within their normal vertical distribution at a depth of approximately $0.25 \mathrm{~m}$. The $H$. sessile field study was conducted in the low intertidal zone on the west side of San Juan Island; relocated plants were collected from near the field study site, suspended from the dock and continuously submerged at a depth of approximately $0.25 \mathrm{~m}$.

Any study of algal phlorotannin levels is complicated by the high intraspecific variation in phlorotannin lev- els within each tissue type (see variances in Table 1). For this reason, attempts to demonstrate induction by comparing a cohort of wounded plants with unwounded controls are likely to result in non-significance (authors' unpubl. data), even though individual plants may show very clear patterns. Under these circumstances, the best way to test for induction is to measure change in phlorotannin level within a given plant through time. Each experiment thus consisted of a series of paired sampling events conducted on a particular species-tissue type (i.e. blade, stipe, holdfast) combination, with a different cohort of plants $(n=5$ to 13 plants) used for each pair of samples. Experiments lasted 7 to $30 \mathrm{~d}$ and took place in May, June, and September, except for a single Agarum fimbriatum blade experiment in December (see Table 1). We assumed that any natural changes in phlorotannin levels over the course of the experimental period were minor (some tests of this are described below), or at least were unlikely to be unidirectional in all plants given the acclimation time between translocations and experiments.

On the first day (Day 0), all plants for a single experiment were wounded ( $\mathrm{n}=18$ to 44 plants, Table 1 ). This initial wound served to: (1) provide tissue for measuring the basal level of phlorotannins present, and (2) provide the damage that could trigger induction of higher levels of phlorotannins. To measure the change in phlorotannin level with time and after damage, a randomly selected subset of Day 0 plants was resampled on a later day, either adjacent or concentric to the Day 0 wound. Thus each paired sampling event provided 2 measures of phlorotannin level: Day 0 (basal level, before simulated herbivory) and Day $n$ (after simulated herbivory). The minimum amount of tissue necessary for phlorotannin analysis was removed during Day 0 and Day $n$ wounding. For each tissue type, this constituted $<5 \%$ of the wet tissue biomass, except in juvenile Laminaria groenlandica blade and adult $L$. groenlandica stipe, in which samples were still $<10 \%$ of the total biomass of each tissue type. Only 1 type of tissue was wounded on each plant thallus. Tissues sampled included the blade meristem (roughly the bottom $1 / 4$ of the blade adjacent to the stipe, where cell division takes place), stipe, and holdfast hapteral branches. Not all tissues were sampled in each species (e.g. Hedophyllum sessile has no stipe). Day 0 phlorotannin values, replicates, and sample weights are listed for all species in Table 1. To look for longerterm changes in phlorotannin levels, control plants of adult $L$. groenlandica and field $H$. sessile were maintained with experimental plants, and samples were taken on the last sampling date (Day 30) to compare control (unwounded) phlorotannin levels with experimental (wounded) levels. 
Table 1 Basal (Day 0) levels of phlorotannins for all plants tested. Sample sizes are indicated parenthetically following basal phlorotannin level. Wet weight of algal tissue collected for each paired sampling event is indicated for each tissue type. Phlorotannin concentrations are given as \% dry weight $\pm 1 \mathrm{SD}$. nc: tissue type not collected

\begin{tabular}{|c|c|c|c|c|}
\hline Tissue wet weight collected: & $\begin{array}{c}\text { Blade } \\
500-800 \mathrm{mg}\end{array}$ & $\begin{array}{c}\text { Stipe } \\
200-600 \mathrm{mg}\end{array}$ & $\begin{array}{l}\text { Holdfast } \\
500-900 \mathrm{mg}\end{array}$ & Sampled \\
\hline Agarum fimbriatum & $7.20 \pm 2.76(37)$ & $7.58 \pm 1.72(40)$ & $4.74 \pm 1.37(44)$ & Sep \\
\hline $\begin{array}{l}\text { Agarum fimbriatum } \\
\text { (single paired sampling event) }\end{array}$ & $14.22 \pm 3.67(20)$ & nc & nc & Dec \\
\hline Pleurophycus gardneri & $5.44 \pm 1.65(39)$ & $7.04 \pm 2.49(43)$ & $4.55 \pm 1.20(40)$ & Sep \\
\hline Laminaria complanata & nc & $2.25 \pm 0.51(20)$ & nc & May \\
\hline Laminaria groenlandica juvenile & $1.65 \pm 0.34(29)$ & nc & nc & Sep \\
\hline Laminariá groenlandica adult & $1.27 \pm 0.34(23)$ & $3.12 \pm 1.07(26)$ & nc & May \\
\hline Hedophyllum sessile field & $4.92 \pm 1.06(18)$ & $\mathrm{nc}$ & $4.68 \pm 0.98(18)$ & Jun \\
\hline Hedophyllum sessile relocated & $5.35 \pm 0.93(36)$ & nc & nc & Sep \\
\hline
\end{tabular}

In wounding the plants, we attempted to mimic herbivore damage observed in the field. Blade tissue is often perforated by gastropod grazers, thus plant blades were wounded with a cork borer (diameter dependent upon size of the plant; 11.5 or $16.5 \mathrm{~mm}$ for Agarum fimbriatum, Pleurophycus gardneri, juvenile Laminaria groenlandica, and relocated Hedophyllum sessile; $8 \mathrm{~mm}$ for field $H$. sessile and adult L. groenlandica). Subsequent samples from blades were taken either concentric to (A. fimbriatum, $P$. gardneri) or adjacent to $(H$. sessile, L. groenlandica adults and juveniles) the original wound.

In the field, stipe damage often consists of furrows and pits, presumably created by grazers and borers. Our first attempt at mimicking this damage was to use a linoleum cutter to carve grooves in the stipe tissue (wounds were $1 \mathrm{~mm}$ deep $\times 3 \mathrm{~mm}$ wide $\times 60 \mathrm{~mm}$ long: adult Laminaria groenlandica, L. complanata). Because the linoleum cutter method did not allow us to easily standardize the depth of the wound, we then switched to wounding with a cork borer 3 or $5 \mathrm{~mm}$ diameter: Agarum fimbriatum, Pleurophycus gardneri). All wounds were created in a way that did not sever the stipe, nor were stipes 'girdled' by removal of all epidermal and outer cortex layers in a ring. Subsequent samples were collected adjacent to the original wounds.

Holdfast damage in the field is often evidenced by pitted or missing haptera, so we used a scalpel to remove the hapteral branch ends (Agarum fimbriatum, Pleurophycus gardneri, field Hedophyllum sessile). Subsequent samples were collected contiguous to the existing wounds. An attempt was made to collect tissue from wounded hapteral branches, but new hapteral tissue was collected if tissue contiguous to previous wounds did not have great enough mass for both extraction and drying procedures.
All tissue samples were stored away from sunlight in capped scintillation vials for 10 min to $6 \mathrm{~h}$ before being divided and weighed on a Mettler AE100 analytical balance $_{i}$ one portion of the tissue was extracted for $24 \mathrm{~h}$ in $10 \mathrm{ml}$ of $80 \%$ methanoi to determine phiorotannin content and one portion was dried in a 50 to $60^{\circ} \mathrm{C}$ oven for $48 \mathrm{~h}$ and reweighed to determine individual wet:dry weight ratios. These ratios were used to convert mg phlorotannin per $\mathrm{ml}$ of methanol to percent phlorotannins per dry weight of plant material.

To determine phlorotannin content, tissue was analyzed using a modified Folin-Ciocalteu assay (Van Alstyne 1995) and compared to a phloroglucinol standard. This colorimetric assay measures total phlorotannin levels and may also be subject to interference by other compounds which are soluble in organic solvents and react positively with the Folin-Ciocalteu reagent. Without integrated ${ }^{13} \mathrm{C}$ nuclear magnetic resonance we cannot state unequivocally that the percent dry weight of phlorotannins reported for these tissues is, in fact, all phlorotannins. Nevertheless, we tested for an inducible change in some Folin-Ciocalteu-positive compound or compounds that we will refer to as phlorotannins. Further study is needed to discover the exact composition of the inducible chemicals we report here.

Waterman \& Mole (1994) discussed the 3 most commonly used colorimetric methods for measurement of total phlorotannins: Folin-Ciocalteu, Folin-Denis, and Price-Butler methods. The Folin-Ciocalteu method is recommended because it gives more color for a given sample and is less prone to interference by non-phenolic compounds than other methods (Waterman \& Mole 1994, Van Alstyne 1995). Additionally, most of the kelp research done in the San Juan Islands has been done with a modified (Van Alstyne 1995) Folin-Ciocalteu procedure (Van Alstyne et al. unpubl. data), and use of 
the same colorimetric measurement allows for some comparisons among results. The reactivity of structurally different compounds to the Folin-Denis assay (and presumably the Folin-Ciocalteu assay) is very similar (Ragan \& Glombitza 1986, Steinberg 1988, Stern et al. 1996). For the Folin-Denis assay, interference of non-phenolic compounds may be on the order of $0.5 \%$ of dry weight (Stern et al. 1996).

Statistical analysis. Since each plant was sampled twice, we calculated per-individual differences in phlorotannin levels for the paired samples from each Day 0 (before simulated herbivory) versus Day $n$ (after simulated herbivory) subset (e.g. Day 0 vs Day 1 for 10 Agarum fimbriatum stipes, Day 0 vs Day 3 for 10 different $A$. fimbriatum stipes). These differences were first inspected for normality using the Shapiro-Wilke test and square-root transformed to achieve normality where necessary prior to performing all statistical tests. If normality was achieved, a paired $t$-test was used to test for differences between Day 0 and Day $n$ phlorotannin levels; otherwise, a non-parametric Wilcoxon Signed-Rank test was employed (Zar 1984). Because each paired sampling event was independent, it was not necessary to control for experiment-wide error. Data were converted to \% change for graphing purposes only.
One-way analysis of variance (ANOVA) was used to examine variability among Day 0 phlorotannin levels for the different groups of plants (e.g. the Agarum fimbriatum stipes resampled on Days 1 vs 3) from each experiment.

For adult Laminaria groenlandica and field Hedophyllum sessile, an F-test was performed to check for homogeneity of variances between Day 30 control (unwounded) and Day o (unwounded) phlorotannin levels, and between Day 30 control and Day 30 wounded phlorotannin levels. Two-sample $t$-tests were then performed for each of these comparisons. All $F$-tests and $t$-tests were performed in Microsoft Excel version 5.0.

\section{RESULTS}

Of the 5 species tested, 4 responded to wounding with a rapid increase in phlorotannin levels (Agarum fimbriatum, Pleurophycus gardneri, Laminaria complanata, and L. groenlandica, Figs, 1 to 3 ). While it is possible that the observed induction was due to other sources of disturbance such as relocation, relocated plants were given several weeks of acclimation time before testing began. Many induction responses were
Fig. 1 Percent change in phlorotannin levels in blade tissues. Time is number of days since initial wounding (Day 0). Statistical results are for paired sample $t$-tests comparing Day $n$ to Day 0 phlorotannin levels p-values for each paired sample $t$-test are indicated above the appropriate bar p-values greater than 0.1 are not significant (NS). Bars are 1 SD. $n=$ number of plants for each paired sampling

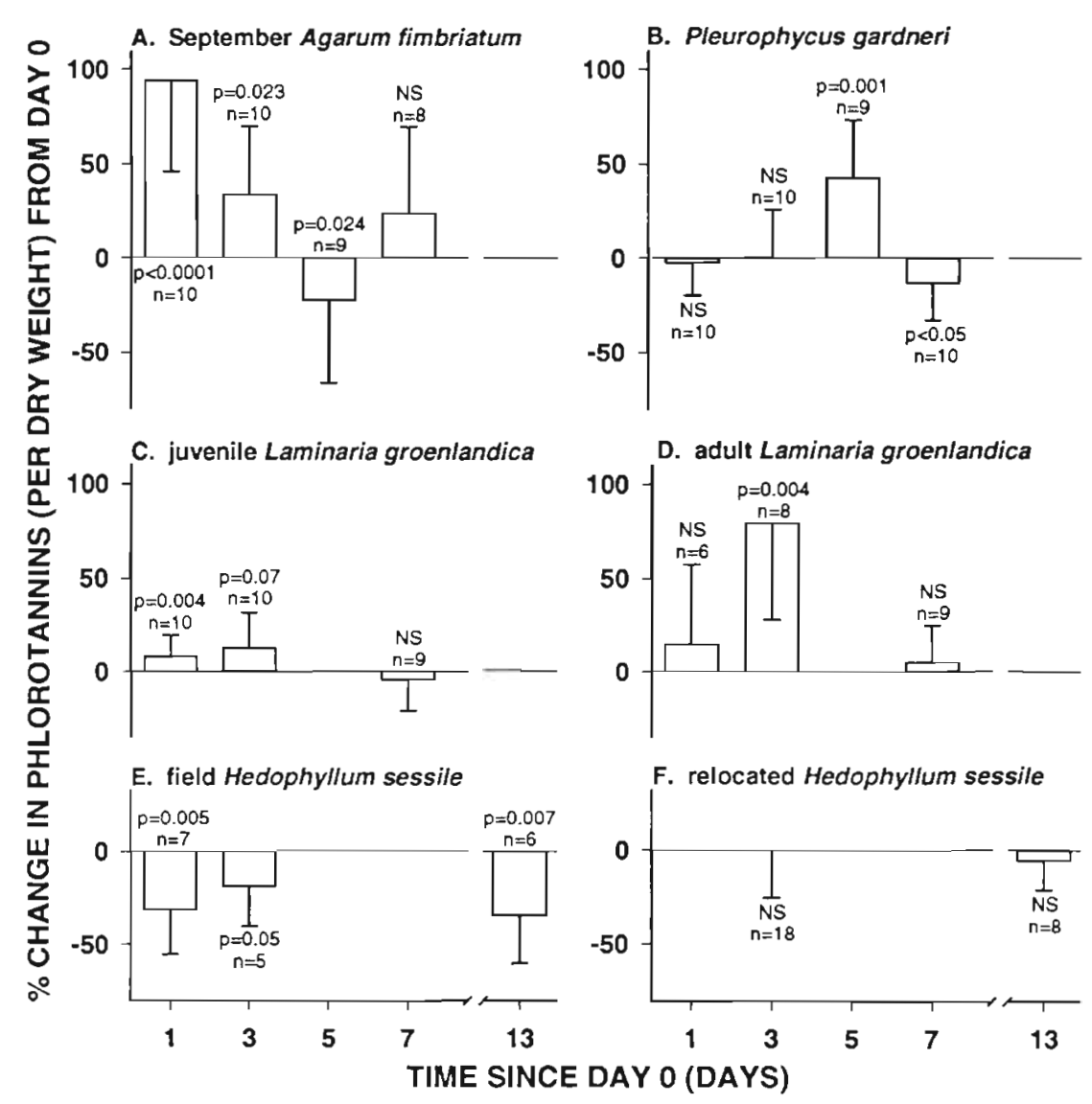




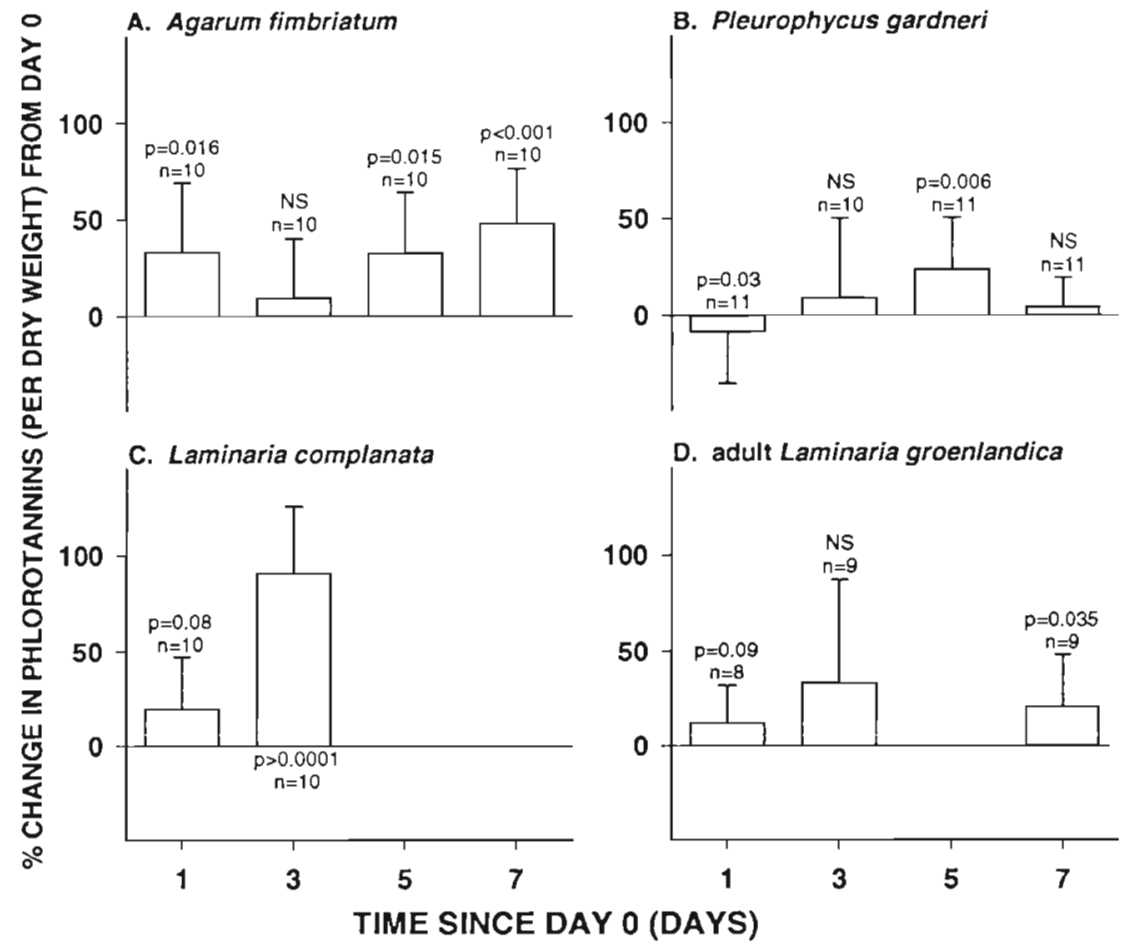

Fig. 2. Percent change in phlorotannin levels in stipe tissues. Time is number of days since initial wounding (Day 0). Statistical results are for paired sample $t$-tests comparing Day $n$ to Day 0 phlorotannin levels. p-values for each paired sample $t$ test are indicated above the appropriate bar. p-values greater than 0.1 are not significant (NS). Bars are 1 SD. $n=$ number of plants for each paired sampling relaxed by Day 7 , so it is likely that any induction response due to relocation would have relaxed long before an experiment began. For most kelps, and most tissues, the increase in phlorotannins was significant, and occurred within 1 to $3 \mathrm{~d}$ following wounding. The Day 0 levels of all species and tissue types varied widely (from 1.5 to $14.2 \%$ dry weight, Table 1 ), but there does not appear to be any correlation between Day 0 level and magnitude of induction, or between tissue type and magnitude of induction (Figs. 1 to 3 ). Blade tissue of both low-phenolic L. groenlandica and high-phenolic A. fimbriatum (September samples) experienced large magnitude ( $>75 \%$ increase) inductions, as did $P$. gardneri holdfast tissue. Likewise, high- phenolic P. gardneri blade and stipe, high-phenolic $A$. fimbriatum stipe and holdfast, and low-phenolic $L$. groenlandica stipe experienced low magnitude $(<50 \%$ increase) induction. Basal phenolic levels in all species were similar to those measured by Van Alstyne et al. (unpubl. data).

With such high variability within each species in Day 0 phlorotannin levels, 1-way ANOVA results (Table 2) comparing Day 0 levels revealed no significant differences among groups of plants within a species (except for a small difference in Pleurophycus gardneri holdfast groups). This consistently high intraspecific variability in phlorotannin levels and the subsequent need for paired-sample testing rather than

Table 2. One-way ANOVA results for differences between sets of Day 0 phlorotannin levels from each paired sampling event within a species-tissue type experiment. Significance is denoted with an asterisk ( $\left.{ }^{\prime}\right)$. nc: not collected

\begin{tabular}{|c|c|c|c|}
\hline Species & Blade & Stipe & Holdfast \\
\hline Agarum fimbriatum (Sep) & $F_{3,33}=2.41, \mathrm{p}=0.08$ & $F_{3.36}=0.70, \mathrm{p}=0.56$ & $F_{3,40}=2.26, p=0.10$ \\
\hline Pleurophycus gardneri & $F_{3.35}=0.63, \mathrm{p}=0.68$ & $F_{3,39}=0.56, p=0.64$ & $F_{3.35}=3.15, p=0.04^{\circ}$ \\
\hline Laminaria complanata & nc & $F_{1.16}=0.10, p=0.75$ & nc \\
\hline \multicolumn{4}{|l|}{ Laminaria groenlandica } \\
\hline Juvenile & $F_{2,26}=1.31, p=0.29$ & $\mathrm{nc}$ & nc \\
\hline Adult & $F_{2,20}=0.33, p=0.72$ & $F_{2.23}=0.61, p=0.55$ & nc \\
\hline \multicolumn{4}{|l|}{ Hedophyllum sessile } \\
\hline Field & $F_{2,15}=0.24, p=0.79$ & nc & $F_{2,15}=1.46, p=0.26$ \\
\hline Relocated & $F_{2.23}=0.31, \mathrm{p}=0.74$ & nc & nc \\
\hline
\end{tabular}




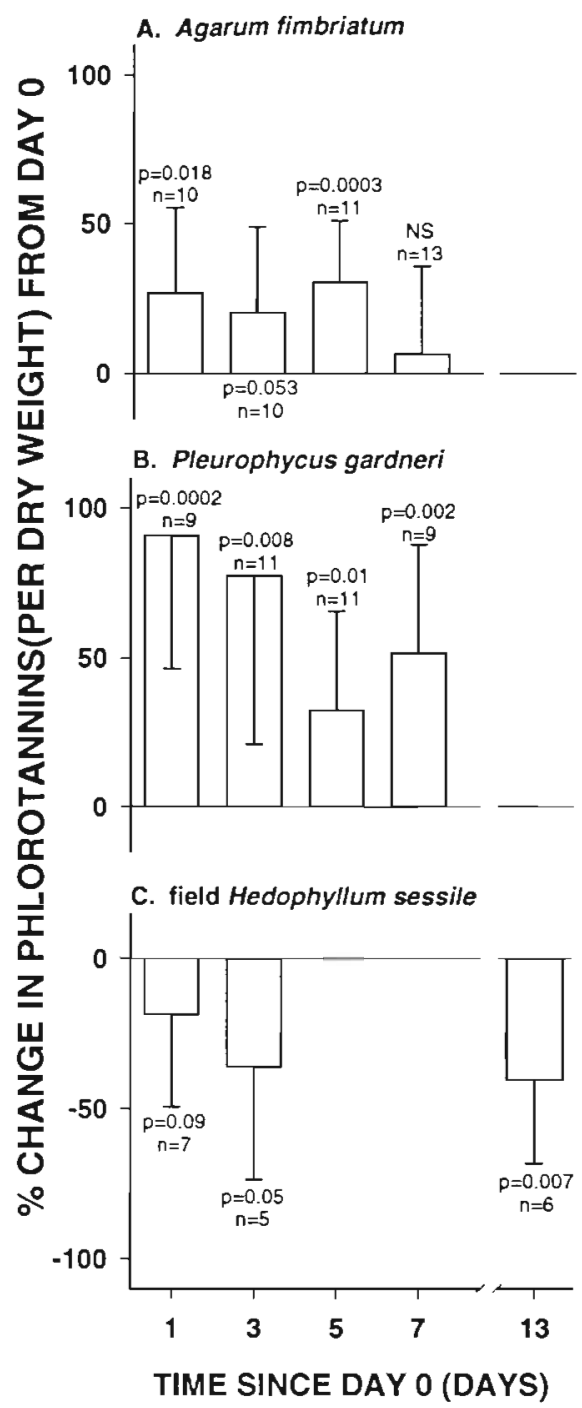

Fig. 3. Percent change in phlorotannin levels in holdfast tissues. Time is number of days since initial wounding (Day 0). Statistical results are for paired sample t-tests comparing Day $n$ to Day 0 phlorotannin levels. p-values for each paired sample $t$-test are indicated above the appropriate bar p-values greater than 0.1 are not significant (NS). Bars are

$1 \mathrm{SD} \cdot \mathrm{n}=$ number of plants for each paired sampling

comparison against controls can be illustrated as follows: Agarum fimbriatum blade (September samples) exhibited the greatest range in phlorotannin levels, from 2.8 to $12.5 \%$ per dry weight on Day 0. Fig. 4 shows the results of the $4 \mathrm{~A}$. fimbriatum blade paired sampling events in September. From Day 0 to Day 1 , plants increased in phlorotannins by $94 \%$, a highly significant increase $(p<0.0001)$. A comparison of Day 1 induced phlorotannin levels with uninduced levels from the 'Day 3' or 'Day 5' paired sampling events would indicate (at least to the eye) no significant differences. Yet phlorotannin levels in every plant in the
Day 0 versus Day 1 paired sampling event increased, and the means are clearly different (Fig. 4). Therefore, paired sample comparisons enable us to follow changes in individual plants over time, without losing information due to the tremendous variability among plants.

\section{Blades}

Significant phlorotannin induction occurred in blade tissues of 4 species, with 2 of those inducing on Days 1 and 3 (Fig. 1). Agarum fimbriatum blade meristem was the most responsive, with phlorotannin levels on Days 1 and 3 increasing by 95 and $33 \%$, respectively (Fig 1A). Three species showed significant decreases in phlorotannin levels (Fig. 1), most notably Hedophyllum sessile. Two other instances of significant decreases occurred in plants that showed significant induction on the previous testing date (Fig. 1A, B).

In Agarum fimbriatum, basal (Day 0) phlorotannin levels were more than 2 times greater in the December experiment than the September experiment (Table 1).

\section{September Agarum fimbrlatum blade results}

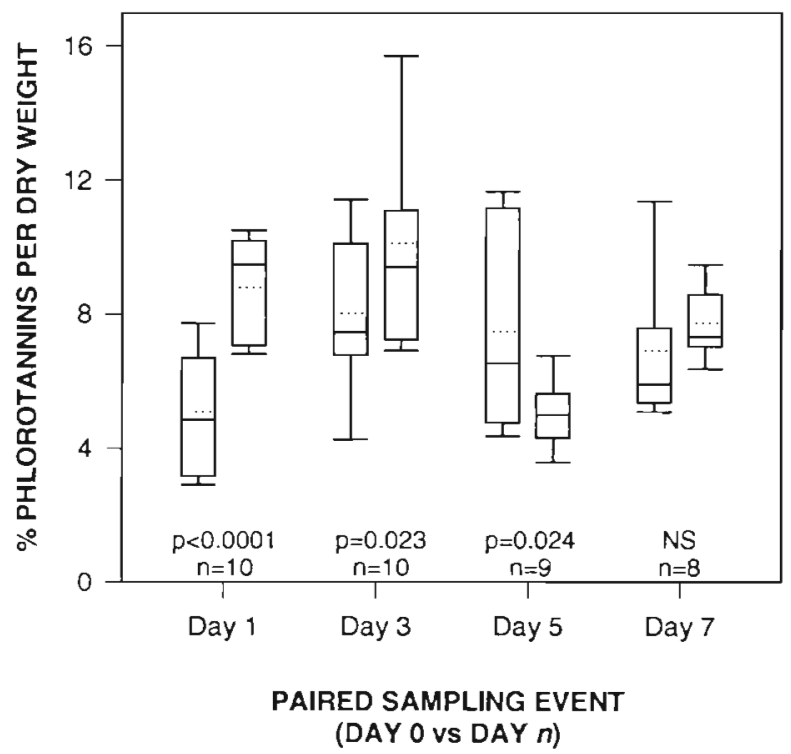

Fig. 4. September induction results for Agarum fimbriatum blade tissue. Absolute levels of phlorotannins (rather than \% change as in Figs. 1 to 3) are shown. Each pair of box plots represents a paired sampling event. The first plot of the pair is the Day 0 level of phlorotannins (before damage); the second plot is the Day $n$ level of phlorotannins (after damage to the same set of plants). Solid lines of each box $=25 \mathrm{th}, 50 \mathrm{th}$, and 75 th percentile points, bars $=5$ th and 95 th percentile points, and dotted lines = means. Sample sizes and $p$-values for each paired sampling event are indicated above the $x$-axis. NS: not significant 


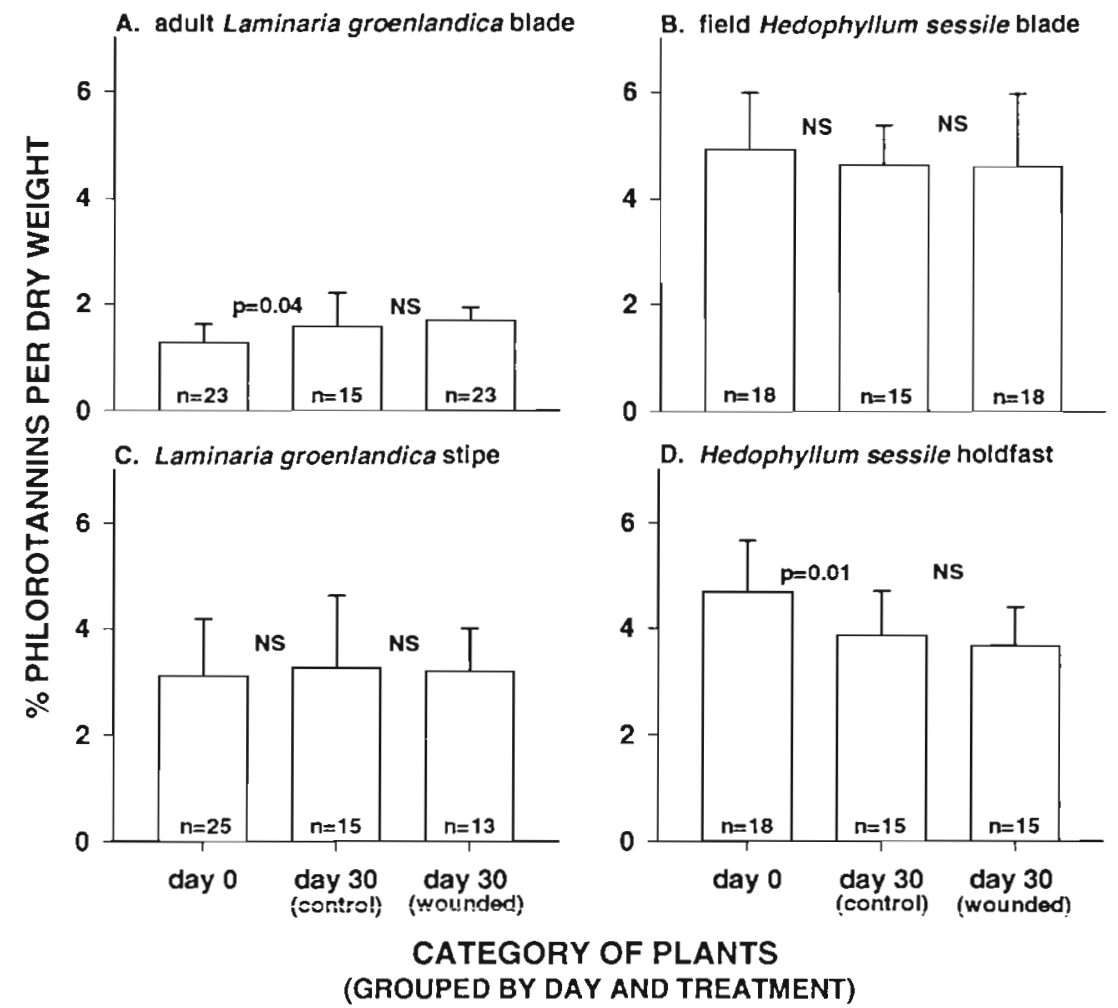

Fig. 5. Comparison of \% phenolics per dry weight for Day 0 plants, Day 30 control plants, and Day 30 wounded plants. Bars are $+1 \mathrm{SD}$ $\mathrm{n}=$ number of plants in each category. Statistical results are for 2sample t-tests on \% phiorotannin levels performed on adjacent bars. NS: not significant
In contrast to September results, December blades did not induce higher levels of phlorotannins, but instead showed a significant decrease in phlorotannins $2 \mathrm{~d}$ after wounding ( $\mathrm{n}=20, \mathrm{p}=0.0007$ ).

Adult and juvenile Laminaria groenlandica blade meristems both showed induction, although their responses were not of the same magnitude. Day 0 values in juveniles were roughly $25 \%$ higher than in adults (Table 1), but the induced responses brought both juveniles and adults up to approximately $1.8 \%$ phlorotannins per dry weight. In juveniles, this $10 \%$ increase was significant from Day 0 to Day 1 and marginally significant from Day 0 to Day 3, although phlorotannin levels in 7 of the 10 sampled Day 3 plants increased (Fig. 1C). In aduIts, phlorotannin levels did not change from Day 0 to Day 1, but increased by $80 \%$ on Day 3 (Fig. 1D). By Day 7, neither juvenile nor adult L. groenlandica phlorotannin levels were elevated over Day 0 values (Fig. 1). Phlorotannin levels in adult control plants suggested there is natural temporal variation in this parameter (Table 3); a 2 -sample $t$-test showed that control (unwounded) Day 30 levels were slightly elevated over Day 0 levels ( $p=0.04$, Fig 5A). Wounded Day 30 levels were not significantly different than control Day 30 levels $(p=0.34$ ), suggesting no long-term effect of the previous induction experiment.

Field and relocated Hedophyllum sessile blades showed similar responses to wounding, although results from relocated blades were not significant. Field blade phlorotannin levels significantly decreased from Day 0 to Day 1, from Day 0 to Day 3, and from Day 0 to Day 13 (Fig. 1E). Two-sample $t$-tests revealed no differences in phlorotannin levels in field $H$. sessile Day 0 and Day 30 control plants ( $p=0.20$, Fig. $5 B$ ), suggesting that temporal variation in phlorotannin levels was low during the experiment (Table 3). Levels in Day 30 wounded and Day 30 control plants were also not different ( $p=0.46)$, showing that the plants had recovered from their earlier loss of phlorotannins. Relocated blade Day 0 phlorotannin levels were slightly elevated over field blade levels (Table 1). Phlorotannin levels of relocated blades did not significantly decrease from Day 0 to Day 3 or from Day 0 to Day 13 (Fig. 1F), but variance in response was very high, with changes in

Table 3. Statistical results of $F$-tests for variances between Day 0 and Day 30 control plants and between Day 30 wounded plants and Day 30 control plants

\begin{tabular}{|c|c|c|c|c|c|c|}
\hline & \multicolumn{3}{|c|}{ Day 0 vs Day 30} & \multicolumn{3}{|c|}{ Day 30 vs Day 30} \\
\hline & $F$ & df & $\mathrm{p}$ & $F$ & df & $\mathrm{p}$ \\
\hline \multicolumn{7}{|c|}{ Laminaria groenlandica } \\
\hline Blade, adult & 0.28 & 22,14 & 0.99 & 1.83 & 22,14 & 0.12 \\
\hline Stipe & 0.62 & 25,14 & 0.82 & 0.35 & 12,14 & 0.97 \\
\hline \multicolumn{7}{|c|}{ Hedophyllum sessile } \\
\hline Blade, field & 2.05 & 17.14 & 0.09 & 3.30 & 17,14 & 0.01 \\
\hline Holdfast & 1.35 & $1.7,14$ & 0.29 & 0.77 & 17,14 & 0.69 \\
\hline
\end{tabular}


phlorotannin levels per thallus ranging from $+25 \%$ to $-40 \%$ between Day 0 and Day 3 .

\section{Stipes}

All 4 species tested showed significant phlorotannin induction in stipes (Fig. 2). Agarum fimbriatum stipe induced on 3 of the 4 testing dates (Fig. 2A), although given the variability among plants, there was no predictable time course for the change in phlorotannin levels. Laminaria groenlandica stipes showed a trend of increasing phlorotannin levels, although this increase was significant only on Day 7 . In only 1 case did a significant decrease in stipe phlorotannins occur, and it was followed $2 \mathrm{~d}$ later by a significant increase (Fig. 2B). In $L$. groenlandica stipe, 2-sample t-tests between Day 0 and Day 30 control phlorotannin levels showed no significant differences ( $p=0.36$, Fig. $5 C$ ), reflecting little temporal variation in phlorotannins during the experiment (Table 3). Day 30 wounded and Day 30 control phlorotannin levels also were not different $(p=0.44)$, showing relaxation of the induction seen on Day 7 .

\section{Holdfasts}

In 2 of the 3 species tested, significant induction occurred in holdfast tissue (Fig. 3). Agarum fimbriatum phlorotannin levels increased roughly $30 \%$ on Day 1 and remained high on Days 3 and 5, while Pleurophycus gardneri responded with persistent, significant increases.

The only decreases in holdfast phlorotannins occurred in field Hedophyllum sessile. Holdfast phlorotannin values decreased from Day 0 to Day 1 in 6 of the 7 plants sampled, but the difference was not significant $(p=0.09)$ because of high variability in the Day 1 measurements $(80 \%$ of the mean). From Day 0 to Day 3 and from Day 0 to Day 13, decreases in phlorotannin levels were significant. Temporal variation in phlorotannins was evident (Table 3); a 2-sample $t$-test between Day 0 and Day 30 control plants showed that control plant phlorotannin levels decreased over this period $(p=0.01)$. There was no difference in phlorotannin levels between Day 30 control and Day 30 wounded plants, however, suggesting that by Day 30 wounded plants had returned to normal, albeit lower, levels ( $p=0.23$, Fig. 5D).

\section{DISCUSSION}

The role of phlorotannin compounds as a constitutive defense against herbivory is well-documented for marine plants (Geiselman \& McConnell 1981, Anderson \& Velimirov 1982, Steinberg 1984, 1985, 1988, Johnson \& Mann 1986, Ragan \& Glombitza 1986, Hay et al. 1988, Van Alstyne \& Paul 1990, Denton \& Chapman 1991, Boettcher \& Targett 1993, Yates \& Peckol 1993, Poore 1994, Steinberg et al. 1995, Cronin \& Hay 1996, Duggins \& Eckman 1997, but for exceptions see Steinberg \& van Altena 1992, Steinberg 1995, Targett et al. 1995). The presumed costs of constitutive defensive chemistry suggest that under some conditions (see 'Introduction') phlorotannins might also be inducible (Van Alstyne 1988, Yates \& Peckol 1993, Steinberg 1994). We demonstrated rapid inducibility of phlorotannins in some species of kelps, an ecologically important group of marine algae in which inducibility previously had not been found. Given the experimental design and the observed longer term temporal variation (Fig. 5), these results should be interpreted conservatively. Nevertheless, short-term inducibility was evident in 4 of the 5 species and in all tissue types (Figs 1 to 3 )

Several mechanisms may account for this induction response. One is translocation of phlorotannins from other parts of the plant. While kelps are physiologically equipped to transport photoassimilates, there are no data to suggest that polyphenolic compounds are associated with sieve tubes. In addition, one of us (K.H.) has data suggesting that phlorotannin levels in Agarum fimbriatum distal blades increased following damage to the meristematic region, which would not be expected if distal blade tissue were 'shipping' its phlorotannins to meristematic wound sites. Thus translocation seems an unlikely explanation for the observed induction. The other possibility is the localized production of more phlorotannins, either by in situ assembly of phlorotannin compounds or by quick conversion of inactive polyphenolic precursors to active phlorotannins (Paul \& Van Alstyne 1992). Our method of testing is incapable of distinguishing between these possibilities, but labeling techniques might be applied successfully in answering these questions.

There was substantial variability among species and among tissue types in the direction, rate, and degree of change in phlorotannin levels. Some of this variation may be an artifact of our experimental design (see below), but at least some may have ecological or evolutionary/historical explanations. For example, Hedophyllum sessile responded differently than the 4 other kelp species tested by displaying an immediate, persistent, and in many cases significant decrease in phlorotannins (Figs. $1 \& 3$ ). $H$. sessile is the only intertidal kelp we examined, which may play a part in its different response, as may effects of relocation, constant submersion, and even season. Other studies suggest a positive correlation between light levels and algal 
phlorotannin concentration (Yates \& Peckol 1993, Pavia et al. 1997) and among light levels, desiccation, and phlorotannin exudation (Sieburth 1969, Ragan \& Jensen 1979, but see Jennings \& Steinberg 1997). The field experiments (run in the spring, when light levels and desiccation both increase abruptly) showed the greatest losses of phlorotannins. The relocation experiments, in the fall, showed smaller (if any) losses, but this result is compounded by possible translocation effects to an unnatural environment (submerged, calm) for this species.

Lowell et al. (1991) also observed a decrease in phlorotannins after herbivore-like damage in an intertidal fucoid, Ascophyllum nodosum (but see Van Alstyne 1988, Yates \& Peckol 1993, Peckol et al. 1996 for exceptions). A. nodosum responded to damage with an induced increase in tensile strength and toughness, which reduced the loss of tissue due to breakage at the point of herbivore damage, a response that may be particularly important to survival in the wave-swept intertidal zone (Lowell et al. 1991). The observed decrease in Hedophyllum sessile phlorotannins may have resulted from catabolic breakdown of phenolic compounds and resynthesis into the structural components necessary to increase strength and toughness (Herms \& Mattson 1992), although Ragan \& Glombitza (1986) reported no evidence for recycling of phlorotannins. Another possible explanation for the decreases in $H$. sessile phlorotannins on Day 1 is leakage. However, loss of cytoplasm ceases several hours after wounding (Faberberg \& Dawes 1976), so presumably active processes caused the continued decreases observed over several days. Some leakage probably always occurs at the wound site, and measures of induced levels of phlorotannins in the other species may actually be underestimated due to this phenomenon.

The induction of phlorotannins we observed in the other 4 species of kelps could be a structural woundhealing, an antibiotic/antimicrobial wound-healing or an anti-herbivore response. In terrestrial plants, deposition of phenolic compounds into wounded and adjacent unwounded tissues occurs as a response to both mechanical and herbivore- or pathogen-induced damage (Tiburzy \& Reisener 1990. Coleman et al. 1992). These elevated levels of phenolic compounds have been shown to prevent pathogenic attacks on the damaged tissue and are hypothesized to precipitate proteins, thereby 'clotting' the wound 'Sieburth \& Conover 1965, Faberberg \& Dawes 1976, Azanza-Corrales \& Dawes 1989). If induction of phlorotannins serves a wound-healing purpose in algae, it seems likely that all tissues of a plant would benefit from induction; this response should be very rapid, but should not persist once the wound is closed. Faberberg \& Dawes (1976) found phlorotannins only during the first stage of wound-healing in stipe tissue of Sargassum filipendula (Phaeophyta, Fucales), and proposed the clotting mechanism of Sieburth \& Conover (1965) as a reason for the presence of phlorotannins. However, the temporal pattern found by Fulcher \& McCully (1969) does not suggest wound-healing. In culture, phlorotannins were immediately lost from the wound site in Fucus vesiculosus tissue and were almost entirely absent $24 \mathrm{~h}$ later; re-establishment of phlorotannins began as early as $5 \mathrm{~d}$ after wounding and was usually complete after $10 \mathrm{~d}$. While all the kelp tissue types are capable of wound-healing or at least wound-clotting (DeWreede et al. 1992, authors' pers. obs.), the delayed (e.g. 3 to $5 \mathrm{~d}$ for some species) or persistent pattern of induction seen in most of our experiments did not follow that expected for a wound-healing function.

Alternatively, induction may be a response to herbivory, such that higher levels of phlorotannins will decrease the probability of future herbivory. In terrestrial plants, insect damage causes induction of natural products, and this response has been shown to reduce further damage by herbivores in some cases (reviewed in Karban \& Myers 1989, Tallamy \& Raupp 1991). Induction as a response to herbivory (both real and simulated) has been demonstrated in a few cases for brown algae (Van Alstyne 1988, Yates \& Peckol 1993, Peckol et al. 1996, but for exceptions see Lowell et al. 1991, Steinberg 1994). The studies showing induction all used simulated herbivory on fucoids; in 2 cases, littorinid snails showed a preference for phenolic-poor or uninduced plants (Van Alstyne 1988, Yates \& Peckol 1993). Because we have observed herbivore damage to all tissue types in the field, we predicted that in order for phlorotannins to serve an anti-herbivory purpose, blades, stipes and holdfasts all should be capable of induction of phlorotannins (although the stipes and holdfasts might be defended in other ways, such as toughness). To be effective, induction for purposes of anti-herbivory should be immediate, but (assuming a cost to chemical production and maintenance) should relax if no further herbivore attacks occurred.

Induction of phlorotannins was seen in all kelp tissue types. Holdfasts of 2 species tested responded with an immediate ( $1 \mathrm{~d}$ after wounding), significant induction of phlorotannins (Fig. 3). Stipe and blade tissue inductions were more variable; 2 species showed immediate induction in both blade and stipe tissue (Figs. 1 \& 2), while in other species induction was significant only after several days. Much of the apparent 'bouncing around' of phlorotannin levels through time may stem from our experimental design; because we were not able to follow individual plants through a time course without effectively rewounding them multiple times, each day's sample consisted of a different cohort of 
plants. Since variation among plants is very high, examination of different cohorts on different days inevitably confounds temporal patterns.

Induction in most kelp tissues was prolonged over a minimum of $3 \mathrm{~d}$. Relaxation rates were more variable; phlorotannin levels returned to pre-wound levels by Day 7 in all of the blade tissues which showed an immediate response. Of the 4 instances of stipe or holdfast tissue showing an immediate induction response, 3 remained significantly elevated on Day 7 . In previous studies testing for induction in brown algae, an induction response was sought 4 to $7 \mathrm{~d}$ (Steinberg 1994), 3 to $7 \mathrm{~d}$ (Peckol et al. 1996), 2 wk (Van Alstyne 1988, Pfister 1992, Yates \& Peckol 1993) or 4 wk (Lowell et al. 1991) after simulated herbivory; our results demonstrate that, in those studies where no induction was observed, induction may have occurred and relaxed before any measurements were made.

The retention of high phenolic levels over 3 to $7 \mathrm{~d}$ appears to be more consistent with the anti-herbivore, rather than the wound-healing, hypothesis. Longer persistence of induction in stipe and holdfast tissue may indicate that largely structural, fleshy tissues respond to wounding differently than more photosynthetic blades. If persistence of the induced response is an active process, it may be a reflection of the associated cost of loss of the affected tissue (by herbivory or infection); stipes and holdfasts may be more important for long-term survival of kelps than are blades.

The temporal response by Pleurophycus gardneri stipe and blade tissue fits neither the wound-healing nor the anti-herbivory hypothesis since both would predict an immediate, rather than a delayed, response. $P$. gardneri is different from the other subtidal species in that the blade is shed in late fall in the San Juan Islands and regenerated from the intercalary meristem shortly thereafter (Germann 1986). P. gardneri blades gradually decrease in dry weight, mannitol, and laminarin content prior to abscission (Germann 1986), and stipe and holdfast tissue contain the majority of nitrogen products (Germann et al. 1987). Thus the annual blade tissue may be relatively less important than the perennial stipe and holdfast. Although this does not explain the delayed induction in the stipe, perhaps the upcoming abscission caused the delayed induction of the blade tissue. If the blade were going to be shed, the plant need not expend energy producing costly natural products to protect it.

Ragan \& Glombitza (1986) and Van Alstyne et al. (unpubl.) reported seasonal variation in phlorotannin levels for kelps. While most of our experiments were conducted in summer, an additional Agarum fimbriatum blade induction experiment was conducted in December. Unlike the September results, in which $A$. fimbriatum blade phlorotannin levels increased by
$95 \%$ in $1 \mathrm{~d}$, phlorotannin levels did not increase in blades in December, but actually decreased. The basal level of phlorotannins in December, however, was $14.2 \%$, more than twice as high as basal levels in September. These results suggest not only seasonal variation in A. fimbriatum basal phenolic levels, but possibly seasonal variation in the induction response for this species. Phlorotannin levels in December may be at a maximum, with further induction simply not possible.

So why should kelps induce phlorotannin production? First, induction may decrease the probability of future attacks by less mobile but unspecialized herbivores, which may have more ecological and evolutionary impacts on seaweeds than previously thought (Chess 1993, Poore 1994, but for exceptions see Carpenter 1986. Hay et al. 1988, Hay \& Steinberg 1992). Although we did not test changes in tissue palatability due to induction, many (but not all) of the increases in phlorotannins in this study were greater than the $20 \%$ increase that deterred herbivores in Van Alstyne's study (1988) (Figs. 1 to 3). Second, mesograzers, although they typically have restricted grazing ranges, may choose plant tissues based on within-plant variation in unpalatable natural products (Poore 1994). Thus a localized induction may encourage a grazer to feed elsewhere on the plant, so that damage is not concentrated in one area of the plant thallus. This response might decrease indirect damage due to herbivory, the loss of tissue due to breakage at grazer-weakened places in the thallus (Lowell el al. 1991). Third, and perhaps most important evolutionarily, induced resistance in plants is characterized by low specificity of the organisms 'targeted' by the chemicals (Karban \& Myers 1989, Krischik et al. 1991, but see Stout et al. 1997). Although we measured only one 'symptom' of induction (phlorotannins), induced responses may incorporate many traits that affect a range of herbivores or pathogens, creating a changing and heterogeneous target to which predators are less likely to adapt (Karban \& Myers 1989). Finally, plants with inducible rather than constitutive defenses respond to unpredictable biotic pressures only when necessary (Karban \& Myers 1989, Harvell 1990, Herms \& Mattson 1992). Increased variability in defense levels and induced defenses create a spatially and temporally changing food source that favors plant fitness by causing herbivores to choose more predictable resources (Karban et al. 1997).

While we have demonstrated rapid induction of phlorotannins in some kelps, more work is clearly needed to elucidate the potential functions of this response. The time scales over which responses are measured need to be short to be ecologically relevant. The persistence of some induced responses indicates that hypotheses concerning relaxation rates need to be 
modified according to tissue type. The lack of data on regeneration processes in brown algae makes it difficult to predict the time course of induction expected for wound-healing purposes. Experiments need to be conducted testing the susceptibility to attack by herbivores and pathogens of tissues with induced defenses, long-term effects of consumption of tissues with induced defenses on consumer fitness, and effects of production of phlorotannins on plant fitness. Ultimately, it may not be possible to ascribe one function to this response; induction of phlorotannins probably alters the suitability of the plant for subsequent use by both herbivores and microbes, which may be a consequence of the low specificity of many plant chemical defenses (Krischek et al. 1991).

Acknowledgements. Field and laboratory assistance were provided by Patricia Wojcik, Chris Siddon, Shawn Kuchta, Sean Avent, and Emily Aring. Earlier drafts of the paper were improved by comments from Jim Eckman, Courtney Richmond, Denise Sanger, Sally Woodin, and 4 anonymous reviewers. Funding was provided by the University of South Carolina Marine Science Program, NSF OCE-9314694 to Jim tckman and D.O.D., andi a Universiiy of vivalhiny ion Royaity Research Fund grant to M.N.D.

\section{LITERATURE CITED}

Al-ogily SM, Knight-Jones EW (1977) Anti-fouling role of antibiotics produced by marine algae and bryozoans. Nature 265:728-729

Anderson RJ, Velimirov B (1982) An experimental investigation of the palatability of kelp bed algae to the sea urchin Parechinus angulosus Leske. PSZN I: Mar Ecol 3:357-373

Arnold TM, Tanner CE, Hatch WI (1995) Phenotypic variation in polyphenolic content of the tropical brown alga Lobophora variegata as a function of nitrogen availability. Mar Ecol Prog Ser 1:23:177-183

Azanza-Corrales R, Dawes CJ (1989) Wound healing in cultured Eucheuma alvarezii var. tambalang Doty. Bot Mar $32: 229-234$

Boettcher AA, Targett NM (1993) Role of polyphenolic molecular size in reduction of assimilation efficiency in Xiphıster mucosus. Ecology 74:891.-903

Carpenter RC (1986) Partitioning herbivory and its effects on coral reef algal communities. Ecol Monogr 56:345-363

Chess JR (1993) Effects of the stipe-boring amphipod Peramphithoe stypotrupetes (Corophioidea: Ampithoidae) and grazing gastropods on the kelp Laminaria setchellix. J Crustac Biol 13:638-646

Coleman JS, Jones CG, Krischik VA (1992) Phytocentric and exploiter perspectives of phytopathology. Adv Plant Pathol 8:167-195

Cronin G, Hay M.E (1996) Susceptibility to herbivores depends on recent history of both the plant and the animal. Ecology 77:1531-1543

Dayton PK (1985) Ecology of kelp communities. Annu Rev Ecol Syst 16:215-245

Dayton PK, Curne V, Gerrodette T, Keller BD, Rosenthal R, Ven Tresca D (1984) Patch dynamics and stability of southern California kelp communities. Ecol Monogr 45:137-159

Denton AB, Chapman ARO (1991) Feeding preferences of gammarid amphipods anong four species of Fucus. Mar
Biol 109:503-506

Denton A, Chapman ARO, Markham J (1990) Size-specific concentrations of phlorotannins (anti-herbivore compounds) in three species of Fucus. Mar Ecol Prog Ser 65: $103-104$

DeWreede RE, Ewanchuk P, Shaughnessy F (1992) Wounding, healing and survivorship in three kelp species. Mar Ecol Prog Ser 82:259-266

Duggins DO, Eckman JE (1997) Is kelp detritus a good food for suspension feeders? Effects of kelp species, age, and secondary metabolites. Mar Biol 128:489-495

Duggins DO, Simenstad CA, Estes JA (1989) Magnification of secondary production by kelp detritus in coastal marine ecosystems. Science 245:170-173

Faberberg WR, Dawes CJ (1976) Studies on Sargassum. I. A light microscope examination of the wound regeneration process in mature stipes of $S$. filipendula. Am J Bot 63 : $110-119$

Fulcher GR, MCCully ME (1969) Histological studies on the genus Fucus. IV Regeneration and adventive embryony Can J Bot 47:1643-1649

Geiselman JA. McConnell oJ (1981) Polyphenols in brown algae Fucus vesiculosus and Ascophyllum nodosum: chemical defenses against the marine herbivorous snail Littorina littorea. J Chem Ecol 7:1115-1133

Germann I (1986) Growth phenology of Pleurophycus gardneri (Phaeophyceae, Laminariales), a deciduous kelp of the northeast Pacific. Can J Bot 64:2538-2547

Germann I, Dreuhl LD, Hoeger U (1987) Seasonal variation in total and soluble tissue nitrogen of Pleurophycus gardneri (Phaeophyceae: Laminariales) in relation to environmental nitrate. Mar Biol 96:413-423

Harvell CD (1990) The ecology and evolution of inducible defenses. Q Rev Biol 65:323-340

Hay ME (1996) Marine chemical ecology: what's known and what's next? J Exp Mar Biol Ecol 200:103-134

Hay ME, Fenical W (1988) Marine plant-herbivore interactions: the ecology of chemical defense. Annu Rev Ecol Syst 19:111-145

Hay ME, Renaud PE, Fenical W (1988) Large mobile versus small sedentary herbivores and their resistance to seaweed chemical defenses. Oecologia 75:246-252

Hay ME, Steinberg PD (1992) The chemical ecology of plantherbivore interactions in marine versus terrestrial communities. In: Rosenthal GA, Berenbaum MR (eds) Herbivores: their interactions with secondary plant metabolites. Academic Press, New York, p 371-414

Herms DA, Mattson WJ (1992) The dilemma of plants: to grow or defend. Q Rev Biol 67:283-335

Jennings JG, Steinberg PD (1997) Phlorotannins versus other factors affecting epiphyte abundance on the kelp Ecklonia radiata, Oecologia 109:461-473

Johnson CR, Mann KH (1986) The importance of plant defence abilities to the structure of subtidal seaweed communities: the kelp Laminaria longicruris de la Pylaie survives grazing by the snail Lacuna vincta (Montagu) at high population densities. J Exp Mar Biol Ecol 97:231-267

Karban R, Agrawal AA, Mangel M (1997) The benefits of induced defenses against herbivores. Ecology 78:1351-1355

Karban R, Myers JH (1989) Induced plant responses to herbivory. Annu Rev Ecol Syst 20:331-348

Krischik VA, Goth RW, Barbosa P (1991) Generalized plant defense: effects on multiple species. Oecologia 85:562-571

Langlois G (1975) Effect of algal exudates on substratum selection by the motile marine telotroch Vorticella marine. J Protozool 221:115-123

Lowell RB, Markham JH, Mann KH (1991) Herbivore-like 
damage induces increased strength and toughness in a seaweed. Proc R Soc Lond B 243:31-38

Mann KH (1973) Seaweeds: their productivity and strategy of growth. Science 182:975-981

Mann KH (1982) Ecology of coastal waters. Blackwell Scientific Publications, Oxford

Martinez EA (1996) Micropopulation differentiation in phenol content and susceptibility to herbivory in the Chilean kelp Lessonia nigrescens (Phaeophyta, Laminariales). Hydrobiologia 326/327:205-211

Paul VJ (1992) Ecological roles of marine natural products. Cornell Press, Ithaca

Paul VJ, Van Alstyne KL (1992) Activation of chemical defenses in the tropical green algae Halimeda spp. J Exp Mar Biol Ecol 160:191-203

Pavia H, Aberg P (1996) Spatial variation in polyphenolic content of Ascophyllum nodosum (Fucales, Phaeophyta). Hydrobiologia 326/327:199-203

Pavia H, Cervin G, Lindgren A, Åberg P (1997) Effects of UV$B$ radiation and simulated herbivory on phlorotannins in the brown alga Ascophyllum nodosum. Mar Ecol Prog Ser 157:139-146

Peckol P, Krane JM, Yates JL (1996) Interactive effects of inducible defense and resource availability on phlorotannins in the North Atlantic brown alga Fucus vesiculosus. Mar Ecol Prog Ser 138:209-217

Pfister CA (1992) Costs of reproduction in an intertidal kelp: patterns of allocation and life history consequences. Ecology 73:1586-1596

Poore AGB (1994) Selective herbivory by amphipods inhabiting the brown alga Zonaria angustata. Mar Ecol Prog Ser 107:113-123

Ragan MA, Glombitza KW (1986) Phlorotannins, brown algal polyphenols. In: Round FE, Chapman DJ (eds) Progress in phycological research. Biopress, Bristol, p 129-241

Ragan MA, Jensen A (1979) Quantitative studies on brown algal phenols. III Light-mediated exudation of polyphenols from Ascophyllum nodosum (L.) Le Jol. J Exp Mar Biol Ecol 36:91-101

Renaud PE, Hay ME, Schmitt TM (1990) Interactions of plant stress and herbivory: intraspecific variation in the susceptibility of a palatable versus an unpalatable seaweed to sea urchin grazing. Oecologia 82:217-226

Rhoades DF (1979) Evolution of plant chemical defense against herbivores. In: Rosentha! GA, Janzen DH (eds) Herbivores: their interaction with secondary plant metabolites. Academic Press, Orlando, p 3-54

Schiel DR, Foster MS (1986) The structure of subtidal algal stands in temperdte waters. Oceanogr Mar Biol Annu Rev $24: 265-308$

Schuitz JC (1988) Plant responses induced by herbivores Trends Ecol Evol 3:45-49

Sieburth JM (1969) Studies on algal substances in the sea. III The production of extracellular organic matter by littoral marine algae. J Exp Mar Biol Ecol 3:290-309

Sieburth JM, Conover JT (1965) Sargassum tannin, an antibiotic which retards fouling. Nature 208:52-53

Simms EL, Rausher MD (1987) Costs and benefits of plant resistance to herbivory. Am Nat 130:570-581

Steinberg PD (1984) Algal chemical defense against herbivores: allocation of phenolic compounds in the kelp Alaria marginata. Science 223:405-407

Steinberg PD (1985) Feeding preferences of Tegula funebralis and chemical defenses of marine brown algae. Ecol Monogr 55:333-349

Steinberg PD (1988) Effects of quantitative and qualitative variation in phenolic compounds on feeding in three spe- cies of marine invertebrate herbivores. J Exp Mar Biol Ecol 120:221-237

Steinberg PD (1994) Lack of short-term induction of phlorotannins in the Australasian brown algae Ecklonia radiata and Sargassum vestitum. Mar Ecol Prog Ser 112 $129-133$

Steinberg PD (1995) lnteraction between the canopy dwelling echinoid Holopneustes purpurescens and its host kelp Ecklonia radiata. Mar Ecol Prog Ser 127:169-181

Steinberg PD, Estes JA, Winter FC (1995) Evolutionary consequences of food chain length in kelp forest communities. Proc Natl Acad Sci USA. 92:8145-8148

Steinberg PD, van Altena I (1992) Tolerance of marine invertebrate herbivores to brown algal phlorotannins in temperate Australasia. Ecol Monogr 62:189-222

Stern JL, Hagerman AE, Steinberg PD, Winter FC, Estes JA (1996) A new assay for quantifying brown algal phlorotannins and comparisons to previous methods. J Chem Ecol 22:1273-1293

Stout MJ, Workman KV, Bostock RM, Duffey SS (1997) Specificity of induced resistance in the tomato, Lycopersicon esculentum. Oecologia 113:74-81

Tallamy DW, Raupp MJ (1991) Phytochemical induction by herbivores. John Wiley, New York

Targett NM, Boettcher AA, Targett TE, Vrolijk NH (1995) Tropical marine herbivore assimilation of phenolic-rich plants. Oecologia 103:170-179

Targett NM, Coen LD, Boettcher AA, Tanner CE (1992) Biogeographic comparisons of marine algal polyphenolics: evidence against a latitudinal trend. Oecologia 89:464-470

Tiburzy R, Reisener HJ (1990) Resistance of wheat to Puccinia graminis f. sp. tritici: association of the hypersensitive reaction with the cellular accumulation of lignin-like material and callose. Physiol Mol Plant Pathol 36:109-120

Tugwell S, Branch GM (1989) Differential polyphenolic distribution among tissues in the kelps Ecklonia maxima, Laminaria pallida, and Macrocystis angustifolia in relation to plant-defence theory. J Exp Mar Biol Ecol 129:219-230

Van Alstyne KL (1988) Herbivore grazing increases polyphenolic defenses in the intertidal brown alga Fucus distichus. Ecology 69:655-663

Van Alstyne KL (1995) Comparison of three methods for quantifying brown algal polyphenolic compounds. J Chem Ecol 21:45-58

Van Alstyne KL, Paul VJ (1990) The biogeography of polyphenolic compounds in marine macroalgae: temperate brown algal defenses deter feeding by tropical herbivorous fishes. Oecologia 84:158-163

Waterman PG, Mole S (1994) Analysis of phenolic plant metabolites. Blackwell Scientific Publications, Oxford

Winter FC, Estes JA (1992) Experimental evidence for the effects of polyphenolic compounds from Dictyoneurum californicum Ruprecht (Phaeophyta: Laminariales) on feeding rate and growth in the red abalone Haliotis rufescens Swainson. J Exp Mar Biol Ecol 155:263-277

Wold EN, Marquis RJ (1997) Induced defense in white oak effects on herbivores and consequences for the plant. Ecology 78:1356-1369

Yates JL, Peckol P (1993) Effects of nutrient availability and herbivory on polyphenolics in the seaweed Fucus vesiculosus. Ecology 74:1757-1766

Zangerl AR, Arntz AM, Berenbaum MR (1997) Physiological price of an induced chemical defense: photosynthesis, respiration, biosynthesis, and growth. Oecologia 109: $433-441$

Zar JH (1984) Biostatistical analysis, 2nd edn. Prentice-Hall Inc, Englewood Cliffs, NJ

Submitted: May 13, 1997; Accepted: February 11, 1998

Proofs received from author(s): March 31, 1998 